УДК 332.146.2: 339.982

\title{
ДЕТЕРМИНАНТЫ ИННОВАЦИОННОГО ПОТЕНЦИАЛА РЕГИОНА В МЕЖДУНАРОДНОЙ СРЕДЕ ДИФФУЗИИ ИННОВАЦИЙ
}

\author{
Э.В. ПАВЛЫШ \\ канд. экон. наук, доцент \\ Полоцкого государственного университета
}

\begin{abstract}
Аннотация
Статья посвящена выявлению ключевых детерминант инновачионного потенцииала региона с учётом его места в региональном пространстве страны и позиций страны в международной среде диффузии инноваций. Систематизированы основные элементы существвующих моделей повыщения инновационного потенциала, предложено структурирование международной среды диффузии инновачий. Дана классификация регионов стран в зависимости от их отношения к международной среде диффузии инноваџий и возможной роли в формировании инновационного потенциала страныл.

Ключевые слова: инновачии, инновационный потенцииал, детерминант инновационного потенциила.

Abstract

The article is devoted to identification of key determinants of regional innovation potential due to its position in countries regional economic space and countries position in international innovation diffusion environment. Main elements of existing innovation potential enhancement models are systematized, international innovation diffusion environment is structured. The classification of countries' regions depending on their relation to international innovation diffusion environment and possible role in forming of countries' innovational development is suggested.

Keywords: innovations, innovative potential, determinants of innovation potential.
\end{abstract}

\section{ВВЕДЕНИЕ}

Инновационный потенциал региона - это комплексная характеристика способности экономических субъектов региона к осуществлению инновационной деятельности. Масштабы инновационной деятельности в регионе определяют тип экономического роста региона (интенсивный или экстенсивный) и, соответственно, вид его развития. Регионы 
со значительным инновационным потенциалом имеют возможность развиваться на основе рационального использования имеющихся внутренних и вовлеченных ресурсов, а регионы с низким инновационным потенциалом демонстрируют значительную зависимость от внешней среды и неспособны адекватно противостоять её негативному воздействию. Таким образом, инновационный потенциал региона, его структура и параметры выступают в качестве основной характеристики способности региона к устойчивому улучшению основных социально-экономических параметров при одновременном повышении эффективности использования базовых ресурсов.

Вопросам состава, структуры и методов наращивания инновационного потенциала региона в разные годы посвящали свои работы многие отечественные и иностранные исследователи, такие как Л. Миляева[1], Г. Жиц [2], С. Егорова [3] и другие. Вместе с тем, изучение закономерностей развития инновационного потенциала региона осуществлялось преимущественно в разрезе ресурсного и институционального подходов к его структурированию. При этом инновационный потенциал региона формируется и используется в многоуровневом экономическом пространстве. Являясь составляющей региона, как социально-экономической территориальной системы макроуровня, инновационный потенциал объединяет в себе макрои микроэкономические субъекты, его функционирование предопределяет последствия как для микроэкономических субъектов, так и для региона и государства в целом (макроуровень), а его развитие происходит под влиянием предприятий, организаций (микроуровень), государственной власти на уровне города, региона и государства в целом (макроуровень) и внешнеэкономического среды (метауровень). Таким образом, стратегические принципы повышения инновационного потенциала региона определяют все три уровня экономического пространства, что обусловливает необходимость исследования их воздействия на региональные инновационные детерминанты.

Исходя из вышеизложенного, целью данной статьи является выявление ключевых детерминант инновационного потенциала региона с учётом его роли в региональном экономическом пространстве страны и отношения к международной среде диффузии инноваций.

\section{РЕЗУЛЬТАТЫ И ИХ ОБСУЖДЕНИЕ}

В данное время не существует единой теории, которая бы позволяла давать однозначный ответ при рассмотрении проблемы степени и характера вмешательства государства в процессы стимулирования 
инновационного развития и повышения инновационного потенциала региона. К традиционным концепциям относятся региональные интерпретации неоклассических и посткейнсианских теорий, а также теории несбалансированного роста. Главная идея неоклассических региональных подходов сводится к тому, что свободный нерегулированный рынок естественным образом приводит к устранению межрегиональных диспропорций. Соответственно региональная политика должна сводиться к устранению препятствий для свободного перемещения труда и капитала между регионами. Посткейнсианская теория допускает государственное регулирование межрегиональных различий. Теория несбалансированного развития прямо противоположна предыдущим: рынок без государственного регулирования усиливает региональные различия через цикличность и самоорганизацию рыночного механизма, закрепляющего высокую развитость одних регионов и экономическое отставание других [4, с. 20].

Следует отметить, что идеи приверженцев первого подхода в полной мере не подтверждались практикой, и государству в той или иной степени приходилось (и приходится) вмешиваться в развитие регионов. По степени влияния государства на региональное развитие В. Мау и К. Янковский выделяют три основных течения [5]:

1) "неинтервенционалистов", в принципе отрицающих необходимость вмешательства государства;

2) "адаптеров", ратующих за смягчение влияния стихийных рыночных сил путем инвестиций и стимулирования миграции рабочей силы;

3) "региональных преобразователей", выступающих за проведение интенсивного регулирования.

Однако на протяжении последних десятилетий в рамках теории эндогенного роста уже разработаны теоретические модели, учитывающие несовершенство ("провалы") как рынка, так и государства [6].

Следует подчеркнуть, что не существует единых общепризнанных моделей регулирования территориального развития и мировая практика очень дифференцирована в зависимости от особенностей и уровня развития национальных экономик, государственного устройства стран, политических традиций и от степени интегрированности национальной экономики в мировое пространство. Лидерами инновационного развития являются экономически развитые страны - США, страны западной Европы, Япония, а также так называемые новые индустриальные страны Азии: Южная Корея, Китай, Тайвань и др. Подходы к повышению инновационного потенциала, реализованные в этих странах, значительно отличаются друг от друга. В общем виде опыт повышения инновационного потенциала регионов в этих странах можно поделить на 3 принципиальные модели - американскую, европейскую и азиатскую (табл. 1). 
Таблица 1 - Принципиальные составляющие современных моделей повышения инновационного потенциала [7, с. 58-59]

\begin{tabular}{|c|c|c|c|}
\hline Тип модели & Американская & Европейская & Азиатская \\
\hline $\begin{array}{l}\text { Стратеги- } \\
\text { ческая цель }\end{array}$ & $\begin{array}{l}\text { Стратегия лидерства. } \\
\text { Обеспечение лидерства } \\
\text { в разработке и } \\
\text { промышленном } \\
\text { внедрении новых } \\
\text { технологий без } \\
\text { принципиальной задачи } \\
\text { лидерства в их } \\
\text { массовом производстве }\end{array}$ & $\begin{array}{l}\text { Стратегия сочиальной } \\
\text { направленности. } \\
\text { Сохранение лидерства в } \\
\text { научно-технической } \\
\text { сфере, защита } \\
\text { присутствия на рынке, } \\
\text { выравнивание } \\
\text { межрегиональных } \\
\text { различий. }\end{array}$ & $\begin{array}{l}\text { Догоняющее } \\
\text { развитие. Импорт и } \\
\text { освоение новейших } \\
\text { технологий со } \\
\text { стратегической целью } \\
\text { дальнейшего развития } \\
\text { технологий на } \\
\text { эндогенной основе }\end{array}$ \\
\hline $\begin{array}{l}\text { Роль } \\
\text { государства }\end{array}$ & $\begin{array}{l}\text { Минимальная: } \\
\text { установление правил } \\
\text { игры на рынке новых } \\
\text { технологий, фискальное } \\
\text { стимулирование } \\
\text { внедрения инноваций в } \\
\text { частном секторе, } \\
\text { создание благоприятной } \\
\text { институционной среды } \\
\text { взаимодействия } \\
\text { университетов и } \\
\text { бизнеса }\end{array}$ & $\begin{array}{l}\text { Координирующая: } \\
\text { разработка } \\
\text { стратегических } \\
\text { направлений НТР через } \\
\text { принятие программных } \\
\text { документов и участие в } \\
\text { финансировании } \\
\text { научно-технических } \\
\text { проектов без } \\
\text { вмешательства в } \\
\text { систему распределения } \\
\text { прав собственности }\end{array}$ & $\begin{array}{l}\text { Прямое } \\
\text { вмешательство: } \\
\text { На первом этапе } \\
\text { создание } \\
\text { государственных } \\
\text { предприятий, на } \\
\text { втором - } \\
\text { формирование } \\
\text { программ } \\
\text { инновационного } \\
\text { развития и } \\
\text { инвестиционной } \\
\text { политики с } \\
\text { расширением участия } \\
\text { частного сектора }\end{array}$ \\
\hline $\begin{array}{l}\text { Развитие } \\
\text { инвести- } \\
\text { ционной } \\
\text { составляющей } \\
\text { инновацион- } \\
\text { ного } \\
\text { потенциала }\end{array}$ & $\begin{array}{l}\text { Поощрение частных } \\
\text { инвестиций через } \\
\text { фискальные стимулы, } \\
\text { развитие венчурных } \\
\text { схем финансирования } \\
\text { малого инновационного } \\
\text { предпринимательства }\end{array}$ & $\begin{array}{l}\text { Покрытие части рисков } \\
\text { инновационной } \\
\text { деятельности через } \\
\text { участие государства в } \\
\text { финансировании } \\
\text { научно-технических } \\
\text { разработок на основе } \\
\text { рамочных программ }\end{array}$ & $\begin{array}{l}\text { Создание } \\
\text { привлекательного } \\
\text { инвестиционного } \\
\text { климата для } \\
\text { поощрения } \\
\text { иностранных } \\
\text { инвестиций в } \\
\text { стратегические } \\
\text { отрасли, прямое } \\
\text { участие государства в } \\
\text { финансировании }\end{array}$ \\
\hline $\begin{array}{l}\text { Развитие обра- } \\
\text { зовательной } \\
\text { составляющей } \\
\text { инновацион- } \\
\text { ного } \\
\text { потенциала }\end{array}$ & $\begin{array}{l}\text { Нормативно-правовая } \\
\text { поддержка } \\
\text { конкурентного рынка } \\
\text { труда, финансирование } \\
\text { образовательных } \\
\text { программ на } \\
\text { конкурсной основе в } \\
\text { форме грантов }\end{array}$ & $\begin{array}{l}\text { Стимулирование } \\
\text { межрегионального } \\
\text { сотрудничества } \\
\text { образовательных } \\
\text { заведений, } \\
\text { финансирование } \\
\text { образовательных } \\
\text { программ }\end{array}$ & $\begin{array}{l}\text { Импорт знаний через } \\
\text { поощрение обучения } \\
\text { специалистам за } \\
\text { границей, создание } \\
\text { государственных } \\
\text { университетов }\end{array}$ \\
\hline
\end{tabular}


Окончание таблицы 1

\begin{tabular}{|c|c|c|c|}
\hline Тип модели & Американская & Европейская & Азиатская \\
\hline $\begin{array}{l}\text { Развитие } \\
\text { научно- } \\
\text { технической } \\
\text { составляющей } \\
\text { инновацион- } \\
\text { ного } \\
\text { потенциала }\end{array}$ & $\begin{array}{l}\text { Нормативно-правовая и } \\
\text { институционная } \\
\text { поддержка } \\
\text { сотрудничества научно- } \\
\text { технических заведений } \\
\text { и бизнеса, } \\
\text { финансирование } \\
\text { фундаментальных } \\
\text { исследований }\end{array}$ & $\begin{array}{l}\text { Финансирование } \\
\text { фундаментальных и } \\
\text { прикладных научных } \\
\text { исследований в } \\
\text { стратегических } \\
\text { отраслях, определенных } \\
\text { наднациональными } \\
\text { программными } \\
\text { документами }\end{array}$ & $\begin{array}{l}\text { Освоение новейших } \\
\text { технологий в } \\
\text { промышленности и } \\
\text { научно-технической } \\
\text { сфере, создание } \\
\text { государственных } \\
\text { научно- } \\
\text { исследовательских } \\
\text { учреждений, } \\
\text { формирование } \\
\text { условий их } \\
\text { сотрудничества с } \\
\text { бизнесом }\end{array}$ \\
\hline
\end{tabular}

Следует отметить, что повышение инновационного потенциала является динамическим процессом, который на каждом отрезке времени зависит от достигнутого уровня экономического, технологического и институционного развития. Поэтому, например, значительное прямое вмешательство государства в инновационную сферу Китая, Японии, Южной Кореи, в том числе и финансовое, имевшее место на первых этапах инициирования инновационного развития, на сегодня меняется на государственную политику поощрения частной инициативы и расширение присутствия частного капитала в инновационной сфере. На определенном этапе инициирования инновационной модели развития экономики в новых индустриальных странах меняют подход к формированию инновационного потенциала, органически замещая широкомасштабное присутствие госсектора бизнес-инициативами, формирование которых стимулируется соответствующей политикой правительств.

Таким образом, логику определения детерминант инновационного потенциала региона необходимо строить с учетом иерархии уровней экономического пространства в следующей последовательности:

во-первых, необходимо структурировать соотношение международного, национального и регионального уровней в формировании инновационных стратегий;

во-вторых, систематизировать отношение национального и международного уровней инновационного среды;

в-третьих, определить влияние национального и международного уровней на содержание регионального развития, что позволит определить принципы выбора общей направленности инновационной стратегии региона и направления повышения инновационного потенциала, и

в-четвертых, определить соотношение регионального и микроэкономического уровней в формировании инновационной стратегии региона и на основе этого сформулировать уточнение 
содержания инструментов повышения инновационного потенциала региона с точки зрения способов и степени вмешательства государства в управление экономикой региона.

Итак, относительно первой задачи, можно отметить, что эффективность регионального развития, базирующегося на внутреннем потенциале, не должна основываться на принципах закрытости от внешней среды. На современном этапе, в условиях активизации глобальных процессов взаимопроникновения национальных экономик, невозможно и нецелесообразно функционирование полностью изолированной территориальной системы, поэтому преимущества оказываются на стороне тех систем, которые наряду со способностью эффективного наращения эндогенного инновационного потенциала демонстрируют способность к оптимальному использованию положительных внешних воздействий и действенному противостоянию негативным внешним факторам.

Повышение инновационного потенциала региона имеет целью активизацию инновационного развития и является элементом инновационной стратегии региона. Направления, формы, методы и средства повышения инновационного потенциала напрямую зависят от формы и содержания инновационной стратегии региона, которая, в свою очередь, определяется состоянием внутренней инновационной среды и ситуацией в межрегиональном и мировом экономическом и научнотехническом пространстве. Формулирование принципов повышения инновационного потенциала, таким образом, невозможно без определения места и функций региона в отношении регионального, национального и мирового уровней экономического пространства.

На национальном уровне регион выполняет функцию обеспечения экономического развития страны в целом. Экономическая среда страны определяет институционные свойства региона и границы его развития. Свойства национальной экономики и задачи её развития в целом определяют отношение региона к мировой системе, особенности его взаимодействия с межрегиональной и международной средой, содержание его инновационной стратегии.

В свою очередь, страна развивается в международной среде, поэтому еe место в международном разделении труда, относительный уровень развития её экономики и её конкурентные позиции в метаэкономическом соревновании детерминируют стратегию её развития так же, как страна детерминирует стратегию развития на региональном уровне.

Таким образом, метауровень экономического пространства опосредованно через национальную экономику оказывает влияние на регион. Исходя из этого, определение инновационной стратегии региона находится под опосредствованным общегосударственным уровнем 
влияния международной среды и невозможно без учета инновационной стратегии развития страны.

Определив соотношение международного, национального и регионального уровней в формировании инновационных стратегий можно перейти к систематизации отношения национального и международного уровней инновационной среды. Стратегия инновационного развития в отношении к преобладающему использованию внутренних или внешних факторов может быть трех типов:

опережающее развитие (эндогенное развитие), когда в инновационной системе формируются передовые технологии, новые не только для данного региона и страны, но и для мира в целом. Эта стратегия - стратегия лидеров, возможности ее применения определяются существующим разрывом между экономикой регионов стран-лидеров и остальным миром.

догоняющее развитие, когда инновационная система лишь использует разработки других для повышения эффективности и ускорения развития собственной экономики. Этот тип развития становился характерным для регионов любой страны, которая выходила на путь сокращения отставания от мировых технологических лидеров и был неотъемлемым этапом модернизации. Впрочем, регионы далеко не каждой страны, которая прибегала к догоняющему развитию, смогли ликвидировать существующий разрыв.

смешанный тип развития, когда импорт инноваций объединяется с разработкой собственных технологий. Этот тип развития для регионов разных стран характеризуется разным соотношением собственных и привнесенных извне инноваций в зависимости от состояния развития каждого отдельного региона каждой отдельной страны. Как правило, переход к этому типу развития основывается на достижениях предшествующего догоняющего развития.

Сегодня инновационные возможности региона и пригодный для него тип инновационной стратегии определяются местом страны, к которой относится регион, в мировой экономической и научно-технической системе. В зависимости от имеющихся ресурсов и свойств внутренней среды в научно-технической, экономической сферах и сфере государственной политики в регионе формируются возможности относительно применения существующих и разработки и внедрения собственных технологий.

Следует отметить, что связь между экономическим ростом и качеством общественных институтов является двусторонней: высокое их качество содействует росту, быстрый рост облегчает совершенствование институтов [8, с. 7]. При этом население разочаровывается в целесообразности реформ и блокирует 
их осуществление, если они не сопровождаются немедленным повышением благосостояния. Обеспечение быстрого роста является необходимым условием формирования благоприятных институциональных ожиданий - самой важной предпосылкой успешности стратегии реализации инновационного потенциала региона. Преждевременная ориентация на эндогенное инновационное развитие может привести к неэффективному использованию ресурсов и в конечном итоге - не к реализации, а к потере потенциала. В этих условиях наиболее приемлемой представляется стратегия заимствования, которая была характерна для регионов большинства азиатских и европейских стран (Япония, Китай, Южная Корея, Португалия и прочие), которые реализовали свой потенциал во второй половине $\mathrm{XX}$ столетия. «Догоняющий» регион имеет возможность выбирать из технологий, уже разработанных в странах-лидерах, которые с высокой степенью вероятности будут содействовать росту благосостояния.

Исследуя процессы экономической глобализации, проф. Д.Г. Лукьяненко приходил к выводу относительно неравномерности, асинхронности и непропорциональности распределения между странами связанных с ней затрат и преимуществ. То есть, возрастающая глобальная взаимозависимость порождает и усиливает системную асимметричность экономического развития. Глобальные экономические асимметрии рассматриваются в контексте асимметрий технологических и информационных, которые, в свою очередь, приводят к технологическому "колониализму" [9, с. 31-34]. В современном мире на фоне процессов стирания национальных границ относительно миграции капитала и информации фактически сформирована среда диффузии инноваций. По отношению к этой среде в общем виде можно выделить четыре типа стран.

Первый тип. Экспортеры инноваций. Это страны с высоким уровнем экономического развития, обусловленным их лидерством в научнотехнической сфере. Они используют имеющийся у них потенциал для ускоренного создания новейших технологий в передовых отраслях экономики, что становится естественным внутренним свойством бизнессреды и уже не нуждается в прямом вмешательстве государства в инновационную сферу (США, Франция, Германия, Япония). Инновационное развитие данных стран является опережающим, а активное взаимопроникновение инновационных систем формируется в соответствии с общими тенденциями мировой экономики, когда взаимодействие между странами высокого уровня экономического развития многократно превышает взаимодействие с другими странами и характеризуется определенным уровнем изоляции, обусловленной на макроуровне 
задачами экономической безопасности и осознания ключевой роли научнотехнического потенциала в макроэкономической конкуренции, а на микроуровне - желанием предприятий сохранить свои конкурентные преимущества в борьбе за потребителей на внутреннем и внешнем рынках. Экспорт технологий происходит по мере их старения через механизмы международного инвестирования, международного научно-технического сотрудничества и международного сотрудничества в сфере высшего образования.

Второй тип. Импортеры инноваций с высоким уровнем развития. Это новые индустриальные страны, которые за счет эффективной инновационной политики государства смогли осуществить структурную перестройку промышленности в направлении увеличения удельного веса высокотехнологических отраслей в промышленности и создать в своей экономике точки технологического роста. Эти страны на сегодня имеют возможность постепенно переходить от догоняющего типа развития к состоянию технологического лидерства, на данном этапе объединяя импорт инноваций с созданием собственных технологических разработок (Южная Корея, Китай и др.). Акценты инновационной политики этих стран смещаются от государственного вмешательства в инновационную среду к институционному регулированию бизнес-среды, а прямая поддержка государства сосредоточивается на научно-техническом и образовательном секторах.

Третий тип. Импортерь инновац̧ий. Это широкий круг развивающихся стран, которые на данном этапе еще не имеют предпосылок создания собственных передовых технологий и лишь пользуются достижениями стран первых двух типов. При этом имеющийся уровень развития и действенность системы управления национальной экономикой позволяет внедрять инновации целенаправленно и системно. В инновационной системе таких стран могут быть собственные разработки, однако их количество незначительно, а их уровень не позволяет утверждать о том, что такие страны существенным образом влияют на формирование международной среды диффузии инноваций.

Четвертый тип. Экспортеры ресурсов. Страны мировой экономической периферии с низким инновационным потенциалом, инновации в экономике которых носят спорадический характер и определяются не задачами развития страны, а внешними факторами. Главным из этих факторов является спрос стран первых двух типов на материальные ресурсы, на основе которого создаются соответствующие производства, которые так или иначе используют новые технологии, однако лишь в незначительных объемах в ограниченном перечне областей экономики. 
Структуру иерархии стран в разрезе их отношение к среде диффузии инновации представлены на рис. 1. Следует отметить, что размежевание между странами второго и третьего типов является довольно условным.

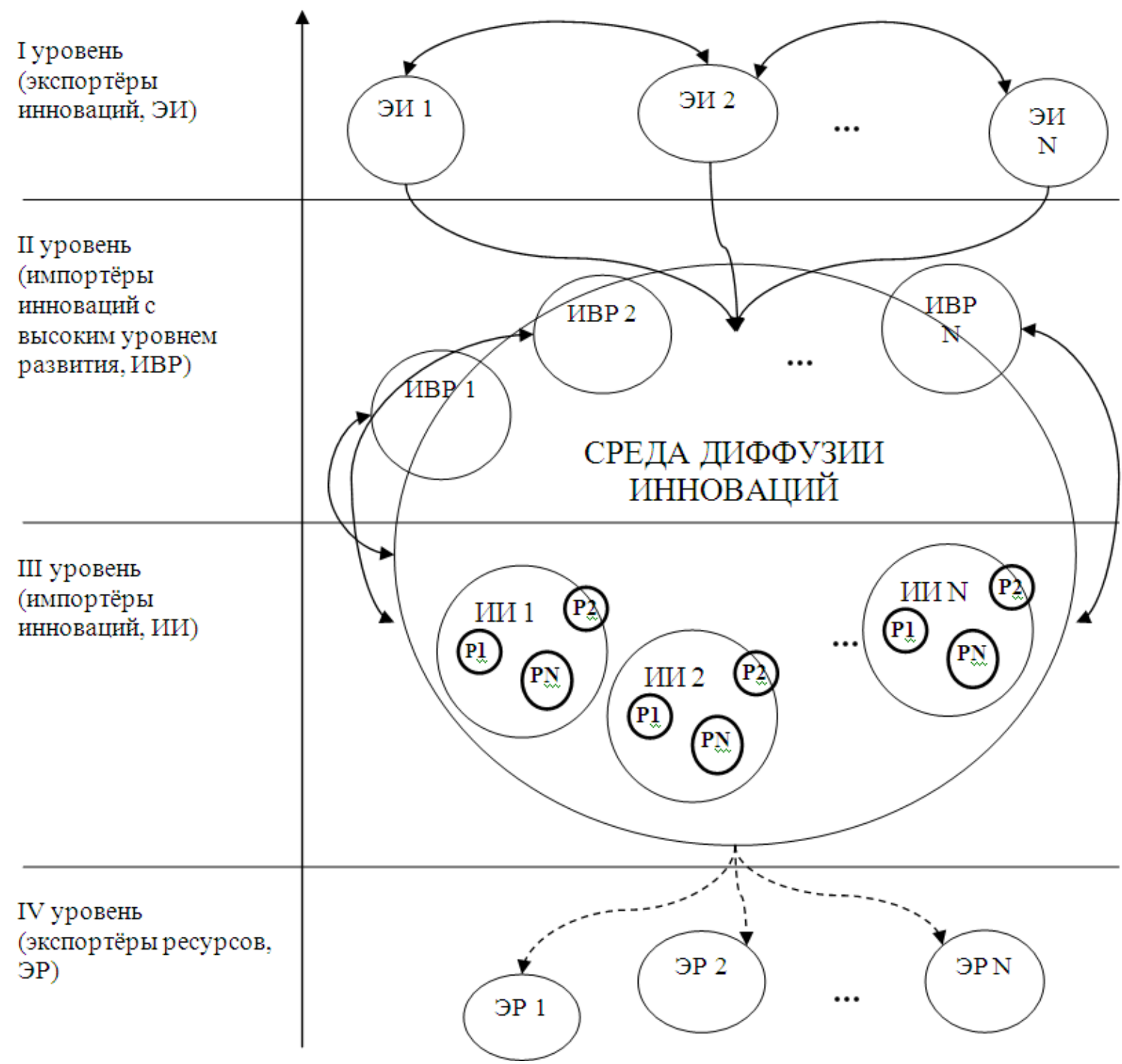

Рисунок 1 - Уровни среды диффузии инноваций

Отдельные страны, будучи импортерами технологий, имеют и собственную среду разработки и внедрения инноваций. Впрочем, технологии, которые разрабатываются в этих странах, используются преимущественно внутри национальных границ и направлены на совершенствование функционирования отраслей устаревших технологических укладов. Главным признаком размежевания второго и третьего типов стран может быть отраслевая структура экспорта. Преобладание в экспорте высокотехнологической продукции свидетельствует о достигнутом высоком уровне используемых 
в стране технологий и является предпосылкой перехода к смешанному типу развития.

Вместе с тем, отраслевая структура экспорта может определяться также и наличием дешевой рабочей силы или благоприятными условиями ведения бизнеса, благодаря чему развитые страны через международные инвестиционные механизмы переносят в эти страны производства, при этом внутренняя научно-техническая сфера этих стран может быть неспособна к формированию собственных разработок.

Также относительно размытым является размежевание третьего и четвертого типа. Это обусловлено нечеткостью размежевания между системным и спорадичным внедрением инноваций. Вообще, главным критерием отнесения стран к третьему или четвертому типу должны быть их макроэкономические показатели, поскольку очевидно, что страны с более высоким уровнем ВВП на душу населения имеют лучшие возможности в формировании инвестиционного ресурса, необходимого для внедрения инноваций. Вместе с тем отдельные страны со сравнительно высоким уровнем доходов (в первую очередь азиатские и африканские страны - экспортеры энергоносителей) фактически не имеют целенаправленной инновационной стратегии и лишь пользуются имеющимися природными ресурсами ради экстенсивного роста.

Нужно также заметить, что прогрессивное перемещение по уровням иерархии стран в отношении к международному инновационному пространству является поэтапным. Существующий мировой опыт имеет примеры быстрой деградации (утрата потенциала развития стран бывшего СССР, быстрый переход из первого на третий- четвертый уровень иерархии в 1990-е), однако не существует примеров, когда страна имела бы возможность перейти с четвертого сразу на второй, или с третьего на первый уровень. Сравнительный анализ опыта развития стран указывает на определенную устойчивую последовательность этапов, которые приходилось проходить тем или иным странам. Это позволяет нам определить динамическую структуру процесса изменения типов развития национальных экономик от экстенсивного (четвертый тип) к эндогенному (опережающее развитие) по отношению к мировому инновационному пространству.

На первом этапе происходит создания материальной основы развития. Осознается необходимость повышения научно-технического уровня экономики и формируются механизмы аккумулирования инновационного потенциала, в первую очередь инвестиционной его составляющей, за счет усиления эксплуатации существующей материально-ресурсной базы (например, опыт модернизации СССР в 1930-е годы на основе стимулирования экспорта агропродукции) или создание предпосылок привлечения внешних ресурсов к экспорто-ориентированному 
росту (Япония, Южная Корея, Китай). Роль государства на этом этапе - доминирующая.

На втором этапе государством формируются механизмы догоняющего развития, которые содействуют активному привлечению заграничных разработок к реформированию существующих и созданию новых производств в национальной промышленности. Одновременно с этим, по мере наращивания внутренних источников инвестиционных ресурсов через диверсификацию экономики, постепенно активизируются процессы развития научно-технического сегмента инновационного потенциала. Повышается материально-техническая база научно-исследовательской деятельности, привлекаются заграничные кадры, повышается квалификация собственных научно-технических кадров. Степень вмешательства государства снижается, а его роль трансформируется от прямого вмешательства в экономические процессы к активному координирующему действию.

На третьем этапе страна постепенно переходит от преобладающего заимствования технологий к созданию собственных. По отношению к инновационному потенциалу это отражается в первую очередь в развитии его образовательного сегмента, в котором активизируются процессы формирования кадров для расширения собственного научнотехнического сегмента.

Четвертый этап - использование преимущественно собственных или по крайней мере созданных на основе международного сотрудничества научно-технических разработок во всех отраслях общественного хозяйства и собственно переход к эндогенному опережающему типу развития. Графически последовательность этапов представлена на рис. 2.

Переходя на региональный уровень, следует в первую очередь согласиться с мнением В.Н. Василенко и П.В. Гудзя, которые утверждают, что "... Неоднородность пространства страны носит объективный характер, не учитывать который не приходится. <..> Как показывает зарубежный опыт (особенно опыт ФРГ после объединения западных и восточных земель), а также отечественная практика выравнивания условий жизнедеятельности социумов на разных территориях, практически невозможно никакими усилиями уменьшить эти отличия. По большому счету эти отличия носят объективный характер и, скорее всего, надо не выравнивать их, а стимулировать усилия, направленные на максимальное использование имеющегося экономического потенциала, a также использовать выделенные "точки роста" как локомотивы развития" [10, с. 16$]$. 


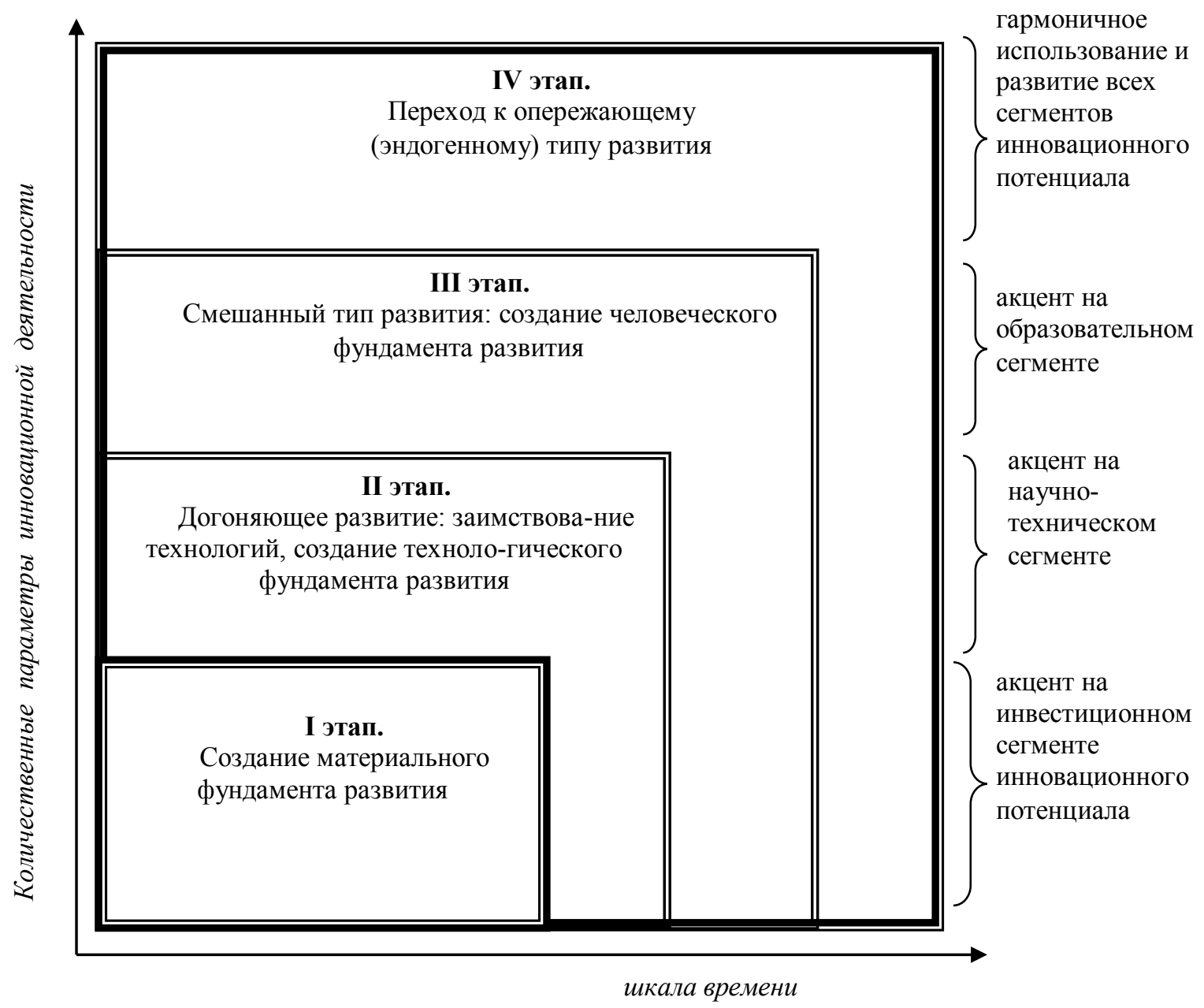

Рисунок 2 - Структура процесса изменения типов развития экономики региона

Развитие региона, в свою очередь, определяется его местом в национальной экономике, то есть сравнительным уровнем его потенциала, в зависимости от которого формируется направленность государственной и внутреннерегиональной политики. На рисунке (см. рис. 1) на третьем уровне международное инновационного пространства сделана краткая детализация регионального уровня для стран третьего типа (элементы P1, P2 ... PN). Если страна не имеет возможности использовать политику опережающего развития, совокупность инновационных возможностей ее ограничена и неравномерно распределяется между территориальными элементами, формируя межрегиональную конкурентную среду. При этом постепенный переход к эндогенному типу развития предусматривает формирование научнотехнических разработок в социально-экономической системе региона. Впрочем, возможности развития на собственной основе определяются рядом факторов, среди которых: 
состояние финансовых ресурсов (инвестиционный сегмент инновационного потенциала);

состояние научно-технического развития (научно-технический сегмент инновационного потенциала);

состояние образовательной системы (образовательный сегмент инновационного потенциала).

Научно-техническая деятельность определяется накопленным (развитым собственными силами, заимствованным, освоенным) уровнем знаний. Появление нового знания невозможно без наличия основы в виде освоенного научно-технического достояния, на основе которого происходит дальнейшее развитие техники и технологий.

Итак, в межрегиональной конкурентной среде можно выделить следующие типы регионов по них отношению к международному инновационному пространству.

1. Регионы, в экономике которых существует возможность создавать сердцевины инновационного роста. Эти регионы способны активно взаимодействовать с международным инновационным пространством, воспринимая нововведение в соответствии с отраслевой структурой своей экономики и (или) создавая в научно-техническом сегменте своего инновационного потенциала собственные разработки. Ключевым признаком таких регионов является развитый инвестиционный сегмент инновационного потенциала в объединении с достаточно развитыми научно-техническим и образовательным сегментами.

2. Регионы, возможность которых к активному взаимодействию с международным инновационным пространством ограничена, однако существуют органические связи с инновационным потенциалом регионов первого типа. Эти регионы, конечно, в современных условиях развитой международной информационной среды имеют возможность привлекаться к изучению передового научно-технического опыта, однако относительная слабость других сегментов экономической системы не дает им возможности в сжатые сроки активизировать процесс практического применения научно-технических разработок. Главное отличие от регионов первого типа - более слабый инвестиционный сегмент инновационного потенциала при сравнительно высоком уровне научно-технического и образовательного сегментов.

3. Регионы, которые отстают как по уровню общеэкономического развития, так и по уровню развития научно-технического и образовательного сегментов. Предпосылки к эндогенному развитию слабые и потому эти регионы напрямую зависят от способностей развития других регионов страны. Ключевой признак - отставание по всем 
сегментам инновационного потенциала, в сочетании со сравнительно низкими темпами экономического роста.

Регионы, свойства которых позволяют им активно взаимодействовать с международной средой диффузии инноваций, на рис. 1 обозначены как Р2. Для определения этих регионов предлагаем использовать термин "регион-медиатор инноваций". Регион-медиатор инноваций - это регион страны догоняющего или смешанного типа развития, свойства которого позволяют ему интегрироваться в международную среду диффузии инноваций и быть в рамках территориальной структуры экономики страны полюсом инновационного развития.

Второй тип регионов можно определить как "регионы-adanmopbl инноваций". Регион-адаптор инноваций - это регион страны догоняющего или смешанного типа развития, свойства которого относительно взаимодействия с международной средой диффузии инноваций ограничены относительно низким уровнем инвестиционного сегменту инновационного потенциала. таким образом, если регион- медиатор имеет внутренние возможности к заимствованию технологий, отраженные в инвестиционном сегменте его инновационного потенциала, то регионадаптор занимает более пассивную позицию, при которой заимствование технологий возможное лишь через инструменты внешнего инвестирования (межрегионального или международного). Вместе с тем, при адекватной инвестиционной политике в создании благоприятного инвестиционного климата регион-адаптор может стать регионом-медиатором.

Третий тип регионов можно определить как "регионы инновационной nериферии". Регион инновационной периферии - это регион страны догоняющего или смешанного типа развития, который по всем параметрам инновационного потенциала отстает от других регионов. Возможности даже экстенсивного развития таких регионов напрямую зависят от развития первых двух типов регионов.

Итак, после решения задачи определения влияния национального и международного уровней на содержание регионального развития можем перейти к задаче выявления соотношения регионального и микроэкономического уровней в формировании инновационной стратегии региона.

Предприятие выступает первичным звеном инновационной системы региона. Именно на уровне предприятия, как элемента региональной инновационной системы, разработанные (заимствованные) научнотехническим сегментом инновационного потенциала научно-технические продукты находят практическое воплощение, которое по определению является необходимой предпосылкой инновационной деятельности. 
При этом предприятие, как структурный элемент экономики региона, ощущает на себе влияние со стороны рыночной среды, на основе чего принимаются решения относительно целесообразности или нецелесообразности осуществления капиталовложений в новейшие технологические процессы и (или) инновационные продукты.

Вместе с тем, рыночная среда в условиях глобализации выходит за пределы отдельных территорий и нарушает тем самым баланс интересов экономических субъектов региона. Интересы предприятия при этом вступают в конфликт с интересами общества в целом, интенсивность и эффективность использования инновационного потенциала региона может снижаться, что отрицательно влияет на выполнение регионом своей целевой функции - обеспечение комфортных условий жизнедеятельности всем расположенным на него территории субъектам.

Именно поэтому процесс использования инновационного потенциала региона требует определенных организационно-экономических механизмов взаимодействия бизнеса и государства, направленных на упорядочение процессов генерации новых идей, поиска и разработки технических решений, создание и внедрение инноваций, создание и своевременную реорганизацию структур, которые осуществляют инновационные процессы, с учетом этапов эволюции продукта, интересов бизнеса и общества в целом.

Активизация распространения новых знаний в экономике требует проведения политики, ориентированной на развитие разных форм партнерских связей. В сфере НИОКР это предусматривает установление разных форм партнерских связей между государственным и частным секторами, которые содействуют передаче знаний и приближению НИОКР к потребностям бизнеса. В этих условиях роль государства на региональном уровне сводится к организации и контролю внутренне и межсекторального взаимодействия и обеспечению восприятия бизнесом необходимых стратегических направлений развития.

Итак, проблема идентификации инновационного механизма не может ограничиваться определенным предприятием или отраслью из-за сложности и многомерности взаимодействия экономических субъектов в инновационном процессе. Инновации возникают в пределах территориальных инновационных систем, которые характеризуются определенными уникальными чертами. Тип развития территории зависит от эффективности использования инновационного потенциала территории, которая в свою очередь зависит от характера влияния на предприятие рыночной среды и существующих механизмов взаимодействия микроэкономических субъектов и органов государственного управления. 


\section{ВЫВОДЫ}

Проведенное исследование позволяет сформулировать ряд выводов, основные из которых сводятся к следующему:

Во-первых, формирование инновационной стратегии региона находится под опосредствованным общегосударственным уровнем влиянием международной среды и невозможно без учета инновационной стратегии развития страны в глобальном экономическом пространстве.

Во-вторых, существует три основных типа инновационного развития страны - догоняющий, опережающий и смешанный. По отношению к международной среде диффузии инноваций в соответствии с преобладанием того или иного типа развития можно выделить четыре типа стран - от стран-экспортеров инноваций до стран- экспортеров ресурсов. При этом переход к высшим типам требует от страны поэтапной эволюции, которая сопровождается поэтапным посегментным повышением инновационного потенциала и способов его использования. Обойти этап догоняющего развития в этой эволюции не представляется возможным.

В-третьих, неоднородность экономического пространства страны позволяет выделить по отношению к международной среде диффузии инноваций три типа регионов - регион-медиатор инноваций, регионадаптор инноваций и регион инновационной периферии. Отличие регионамедиатора от региона-адаптора состоит в большей степени развития инвестиционного сегмента инновационного потенциала.

В-четвертых, первичным звеном инновационной системы региона выступает предприятие, при этом под воздействием рыночной среды интересы предприятия могут вступать в конфликт с интересами общества в целом. Устранение возникающего дисбаланса интересов требует определенных организационно-экономических механизмов взаимодействия бизнеса и государства, направленных на упорядочение процессов создания и (или) заимствования новых технологий, внедрения инноваций, создание и своевременную реорганизацию структур, осуществляющих инновационные процессы, с учетом этапов эволюции продукта, интересов государства, бизнеса и общества в целом.

Построение вышеуказанных механизмов требует разработки теоретико-методологических основ их формирования и функционирования на основе детального анализа внутренней и внешней среды, текущего состояния и потенциала развития конкретных территорий, что представляется перспективным направлением дальнейших исследований данного вопроса. 


\section{ЛИТЕРАТУРА}

1. Миляева Л. Уточнение понятия инновационный потенциал, базирующееся на методике структурированных процедур [текст] / Л. Миляева, Д. Белоусов // Инновации. - 2008. - №12. - С. 100-102.

2. Жиц Г. И. Способности и возможности: рассуждения о некоторых аспектах методологии оценки влияния инновационного потенциала на развитие социально-экономических систем различного уровня сложности [текст] / Г. И. Жиц // Инновации. - 2008. - №11. - С.83-87

3. Егорова С.Е. Инновационный потенциал региона: сущность, содержание, методы оценки [текст] / С. Е. Егорова, Н.Г. Кулакова // Вестник ПсковГУ. Серия «Экономические и технические науки». - 2014. №4. - C. 54-67

4. Реутов В.Е. Генезис теоретичних поглядів на регіон та регіональний розвиток [текст] / В.Е. Реутов, Н.З. Головченко // Економіка та держава. 2010. - №3. - C. 17-22.

5. Мау В., Янковский К. Политические и правовые факторы экономического роста в российских регионах [текст] / В. Мау, К. Янковский // Вопросы экономики. - 2001. - №11. - С. 17-33.

6. Persson T. Political Economics / T. Persson, G. Tabellini. // Explaining Economic Policy. - Cambridge Massachusetts: The MIT Press, 2000. -533 p.

7. Організаційне забезпечення підвищення інноваційного потенціалу регіону: монографія [текст] / В.М. Василенко, Е.В. Павлиш, С.Ю. Юрченко // Наук. ред.: Василенко В.М. - Донецьк: "ВІК", 2013 - 205 с.

8. Полтерович В. Стратегии модернизации, институты и коалиции [текст] / В. Полтерович // Вопросы экономики. - 2008. - №4. - С. 4-24.

9. Лук'яненко Д.Г. Суперечності та асиметрії глобалізації у євроінтеграційному контексті // Спільний європейський економічний простір: гармонізація мегарегіональних суперечностей: монографія [текст]; за заг. ред. Д.Г. Лук’яненка, В.І. Чужикова. - К.: КНЕУ, 2007. - С. 31-47.

10. Василенко В.Н., Гудзь П.В. Парадигма пространственного развития регионов: от обоснования теории к практике реализации [текст] / В.Н. Василенко, П.В. Гудзь // Экономика и управление. - 2011. № 3. - C. 14-20.

Статья поступила в редакичюю 07 ноября 2016 года. 